$\xi^{2}=-1$

\title{
Irrigation groundwater quality based on hydrochemical analysis of Nandgaon block, Nashik district in Maharashtra
}

\author{
K. R. Aher ${ }^{1 *}$, S. G. Gaikwad ${ }^{2}$ \\ ${ }^{1}$ Groundwater Survey and Development Agency, GSDA, Central Administrative Building, \\ Collectoral office, 2nd floor, Fazalpura, Aurangabad-431001 (M.S.) India \\ ${ }^{2}$ Groundwater Survey and Development Agency, GSDA, Jalna-431213 (M.S.) India \\ *Corresponding author E-mail: kailashgis@gmail.com
}

\begin{abstract}
To identify the sources and quality of groundwater, the water samples were collected from 52 dug wells irrigation water in an area of $1089.82 \mathrm{~km} 2$ and were analyses for $\mathrm{pH}$, Conductivity, total dissolved solids, Calcium, Magnesium, Sodium, potassium, total hardness, Alkalinity $\left(\mathrm{CO}_{3}{ }^{2-}, \mathrm{HCO}_{3}{ }^{-}\right)$, sulphate, chloride, nitrate and fluoride to understand the (irrigation water quality index ) IWQI, The secondary parameters of irrigation groundwater quality indices such as Sodium adsorption ratio (SAR), Residual sodium carbonate (RSC), Kelley's ratio (KR), Sodium soluble percent (SSP), Permeability index (PI),Magnesium adsorption ratio (MAR),and CRI (Corrosively ratio index) were calculated from the primary parameter for irrigation water quality index (IWQI). The IWQI was classified into excellent to unfit condition of groundwater quality based on their Water Quality Index (WQI). The IWQI $(88 \%+12 \%)$ indicate that slightly unsustainable to good quality of ground water. But due to this quality deterioration of shallow aquifer, an immediate attestation requires for sustainable development.
\end{abstract}

Keywords: Groundwater Quality; Irrigation Water Quality Indices; Nandgaon Block.

\section{Introduction}

India is a vast country with a highly diversified hydro geologic set-up. The ground water behavior in the Indian sub-continent is highly complicated due to the occurrence of diversified geological formations with considerable lithological and chronological variations, complex tectonic framework, climatologically dissimilarities and various hydrochemical conditions. Quality of water is assuming great importance with the rising pressure on agriculture and rise in standard of living (Wijnen, 2012; Wani et al, 2014 Aher et al, 2015). Groundwater is a vital natural resource for the reliable and economic provision of potable water supply in both the urban and rural environment. It thus plays a fundamental role in human well-being, as well as that of some aquatic and terrestrial ecosystems. In the background of preserving this most important natural asset, water utility management is the key area that managers need to focus upon. Fresh and clean water is of fundamental importance to the survival, protection and development of human needs, as well as for the conservation of the environment. The movement of groundwater is controlled by physical and geochemical properties of (i) contaminant (ii) the groundwater and (iii) the geological system through which the contaminated groundwater is flowing. Presence of some substances beyond certain limits may make it unsuitable for irrigation, domestic or industrial uses (Purushtotham et.al, 2011). Groundwater quality is as important as the quantity. Poor quality of water adversely affects the plant growth and human health (US Salinity Laboratory Staff 1954). Adverse conditions increase investment in irrigation and health, and decrease agricultural production, which, in turn, reduces agrarian economy and retards improvement in the living conditions of rural people. A number of studies on groundwater quality with respect to drinking and irrigation purposes have been carried out in the different parts of the country (Datta, and Tyagi, 1996; Kaply, et. al.,1998; Pawar, et. al., 1998; Subba Rao, et al. 1991; Tatawat \& Chandel, 2008; Deshpande and Aher, 2009; Vijay, et.al. 2010; Anbazhagan \& Balamurgan, 2014; Rao \& Rao,2015), In recent times, there has been a tremendous increase in demand for fresh water due to population growth and intense agricultural activities. The hydrogeologic factors controlling recharge and hydrogeochemical reactions are so important for the chemical constituents to reach the groundwater uses (Raju, 2007). Quality of water is an important consideration in any appraisal of salinity or alkali conditions in an irrigated area. All irrigation water contains some salts, but the concentration and nature of salts vary. The quality of irrigation water depends primarily on the total amount of salt present and the proportion of $\mathrm{Na}+$ to other cation and certain other parameters (Shashi Kant, et al, 2015). Rajankar et al. (2009) calculated WQI for different groundwater sources, viz., dug wells, bore wells, and tube wells at Khaperkheda Region, Maharashtra. The problems of water quality are more acute in areas that are densely populated thickly industrialized and have shallow water set (Gowd, 2005). Keeping view above facts, present study is undertaken to assess the shallow groundwater quality of Nandgaon block in Nashik district, Maharashtra for irrigation purposes through different ground water quality indices and generate WQI.

\section{Physiography and climate of the study area}

The study area forms part of Western Ghat and Deccan Plateau covering an area of $1089.82 \mathrm{~km}^{2}$. Physiographically comprises varied topography. The main system of hills is Sahayadri and its 
offshoots. The climate of the Nandgaon is on the whole is agreeable. The winter season is from December to about the middle of February followed by summer season which last up to May. June to September is the south-west monsoon season, whereas October and November constitute the post-monsoon season. The maximum temperature in summer is $42.5^{\circ} \mathrm{C}$ and minimum temperature in winter is less than $5.0^{\circ} \mathrm{C}$. The average annual rainfall is $467 \mathrm{~mm}$. Agriculture is the main occupation of the people of the area.

\subsection{Geology and hydrogeology}

The entire study area is underlain by the basaltic lava flows of upper Cretaceous to lower Eocene age. These flows are normally horizontally disposed over a wide stretch and give rise to table land type of topography also known a plateau. These flows occur in layered sequences and represented by massive unit at the bottom and vesicular unit at the top of the flow. The shallow alluvial formation of recent age also occurs as narrow stretch along the banks of Rivers flowing in the area. The ground water in Deccan Trap Basalt occurs mostly in the upper weathered and fractured parts down to $15-20 \mathrm{~m}$ depth. At places potential zones are encountered at deeper levels in the form of fractures and interflow zones.

Table 1: Analytical Data from the Groundwater Samples from the Study Area

\begin{tabular}{llllllllllllll}
\hline Parameter & $\mathrm{pH}$ & $\mathrm{EC}$ & $\mathrm{TDS}$ & $\mathrm{Na}^{+}$ & $\mathrm{K}^{+}$ & $\mathrm{Mg}^{2+}$ & $\mathrm{Ca}^{2+}$ & $\mathrm{TH}$ & $\mathrm{HCO}_{3}$ & $\mathrm{SO}_{4}^{2-}$ & $\mathrm{Cl}^{-}$ & $\mathrm{NO}_{3}^{-}$ & $\mathrm{F}^{-}$ \\
\hline Min & 6.16 & 396.00 & 257.40 & 13.00 & 0.10 & 3.84 & 8.00 & 84.00 & 88.00 & 20.00 & 36.00 & 0.22 & 0.01 \\
Max & 8.40 & 2600.00 & 1690.00 & 220.00 & 2.30 & 99.84 & 160.00 & 816.00 & 676.00 & 210.00 & 304.00 & 230.80 & 1.96 \\
Avg & 7.57 & 995.27 & 646.93 & 83.26 & 0.66 & 36.92 & 46.68 & 270.54 & 229.62 & 72.33 & 98.77 & 67.15 & 0.70 \\
Mean & 7.57 & 995.27 & 646.93 & 83.26 & 0.66 & 36.92 & 46.68 & 270.54 & 229.62 & 72.33 & 98.77 & 67.15 & 0.70 \\
\hline
\end{tabular}

*all parameter in $\mathrm{mg} / \mathrm{l}$ except $\mathrm{pH}$ and $\mathrm{EC}$ in $\mu \mathrm{S} \mathrm{cm}^{-1}$

Water quality secondary parameters name SAR, RSC, SSP; KR MAR, CR and PI were analyzed for IWQI. The statistical analysis of various quality parameters IWQI was classified into excellent to unfit condition of groundwater quality based on their Water Quality Index (WQI). Based on their severity of WQI it can be further classified into good to pour good state of groundwater quality for sustainable development.

\section{Irrigation water quality indices (IWQI)}

The various irrigation water quality indices were derived from the primary parameter of drinking water quality. Groundwater utilized for irrigation is an essential aspect in productivity of crop, its yield and quality of irrigated crops. The quality of irrigation groundwater depends mostly on the occurrence of dissolved salts and their concentrations. Sodium adsorption ratio (SAR) and residual sodium carbonate (RSC) are the mainly significant quality decisive factor, which persuade the groundwater quality moreover its fittingness for irrigation. The total salt concentration, sodium soluble percentage (SSP), residual sodium carbonate (RSC), sodium adsorption ratio (SAR) and Kelley index (KI) are the important parameters used for assessing the suitability of water for irrigation uses (Ayers and Westcot, 1985). The various irrigation water quality indices were derived from the primary parameter of drinking water quality (Table, 2 ).

\subsection{Electrical conductivity}

It was a measurement of all soluble salts in samples, the most significant water quality standard on crop productivity which was the water salinity hazard. The primary effect of high EC water on crop productivity was the failure of the plant to compete with ions in the soil solution for water. The higher the EC, the lesser the water available to plants, even though the soil may show wet, because plants can only transpire "pure" water; useable plant water in the soil solution decreases significantly as EC increases. The amount of water transpired through a crop was directly related to yield; therefore, irrigation water with high EC reduces yield potential. In the study area, the classification for EC is given (Handa, 1969, Reddy, 2013) in Table 3. It indicated that overall

\section{Methods of investigation}

Fifty two groundwater samples from different villages of the study area were collected during pre-monsoon season and analyzed for major parameters (Table1). In the present study, samples were collected in pre cleaned polyethylene containers of one litre capacity. The samples were collected from those wells only which are extensively used for drinking and irrigational purposes. Field samples were analyzed immediately (APHA, 1992) for hydrogen ion concentration $(\mathrm{pH})$ and electrical conductivity (EC), using $\mathrm{pH}$ and EC meters. Total dissolved solids (TDS) were computed by using the formula $0.64 \times \mathrm{EC}$. Total hardness $(\mathrm{TH})$ as $\mathrm{CaCO}_{3}$ and calcium $(\mathrm{Ca})$ were analyzed titrimetrically, using standard EDTA. Magnesium (Mg) was calculated by taking the differential value between $\mathrm{TH}$ and $\mathrm{Ca}$ concentrations. Total alkalinity (TA) as Ca$\mathrm{CO}_{3}$, bicarbonate $\left(\mathrm{HCO}_{3}\right)$ were estimated by titrating with $\mathrm{HCl}$. Chloride $(\mathrm{Cl})$ was determined titrimetrically by standard $\mathrm{AgNO}_{3}$ titration, sodium $(\mathrm{Na})$ and potassium $(\mathrm{K})$ were determined by using flame photometer. Sulfate measured by $\mathrm{BaCl}_{3}$ method using spectrophotometer. Nitrate was estimated by using an ion selective electrode. The results of analysis are tabulated in Table 1.

the water quality was medium to high EC category except one sample showing very high EC.

\subsection{Sodium adsorption ratio (SAR)}

The sodium or alkali hazard in the irrigation water are expressed in terms of sodium adsorption ratio (SAR) and classified into four categories as $\mathrm{S}_{1}(\mathrm{SAR}<10), \mathrm{S}_{2}(10-18), \mathrm{S}_{3}(18-26)$ and $\mathrm{S}_{4}(>26)$. The sodium adsorption ratio values for each water sample were calculated by using equation (Richards,1954), and all the samples fall in excellent $\left(\mathrm{S}_{1}\right)$ category (Table, 2 ) indicating that these groundwater sources are suitable for irrigation purpose with no danger of exchangeable sodium.

\subsection{Soluble sodium percentage (SSP)}

Wilcox (1955) has proposed classification scheme for rating irrigation water on the basis of soluble sodium percentage (SSP). . The Soluble sodium percentage varies from 0.57 to 9.57 , with mean value of $3.62 \mathrm{meq} / \mathrm{L}$ (Table, 2). The values of SSP less than 50 indicate good quality of water and higher values (i.e.>50) show that the water is unsafe for irrigation (USDA, 1954). As per these criteria the groundwater is safe for irrigation purpose.

\subsection{Residual sodium carbonate (RSC)}

A high salt concentration in water leads to formation of saline soil and alkaline earth metal cations, expressed as residual sodium carbonate (RSC) are also influencing the water quality for irrigation purposes (Karanth,1987). The $\mathrm{HCO}_{3}{ }^{-}$and $\mathrm{CO}_{3}{ }^{-}$in the irrigation water tend to precipitate calcium and magnesium ions in the soil resulting in an increase in the proportion of the sodium ions. For this reason, RSC was considered as an indicative of the sodicity hazard of water. A high value of RSC in water leads to an increase in the adsorption of sodium on soil (Eaton, 1950). RSC values indicate that in general groundwater is suitable for irrigation purposes (Table 2). 
Table 3: Irrigation Water Quality Based on EC Values

\begin{tabular}{llll}
\hline $\mathrm{EC}(\mu \mathrm{S} / \mathrm{cm})$ & Class & No of Samples & \% No. of samples \\
\hline $0-250$ & Low & Nil & Nil \\
$251-750$ & Medium & 15 & 28.84 \\
$751-2250$ & High & 36 & 69.23 \\
$2251-6000$ & Very high & 1 & 1.92 \\
\hline
\end{tabular}

Table 2: Water Quality Classification Based on Water Quality Index Value

\begin{tabular}{|c|c|c|c|c|c|c|c|c|}
\hline Sample No. & SAR & RSC & KR & SSP & PI & MAR & $\mathrm{CR}$ & IWQI \\
\hline 1 & 2 & 3 & 4 & 5 & 6 & 7 & 8 & 9 \\
\hline 1 & 2.42 & 0.41 & 0.88 & 3.32 & 75.58 & 89.43 & 0.05 & 172.09 \\
\hline 2 & 1.77 & -2.49 & 0.56 & 2.78 & 56.32 & 47.97 & 0.06 & 106.97 \\
\hline 3 & 2.37 & -2.12 & 0.64 & 4.43 & 58.18 & 56.41 & 0.10 & 120.02 \\
\hline 4 & 4.47 & -1.06 & 1.92 & 5.20 & 82.01 & 40.78 & 0.14 & 133.46 \\
\hline 5 & 1.29 & -0.15 & 0.44 & 1.90 & 63.16 & 66.91 & 0.03 & 133.57 \\
\hline 6 & 1.79 & -2.66 & 0.56 & 2.87 & 55.46 & 58.06 & 0.09 & 116.17 \\
\hline 7 & 1.38 & -1.58 & 0.45 & 2.09 & 57.18 & 51.31 & 0.06 & 110.88 \\
\hline 9 & 2.28 & 0.10 & 0.80 & 3.24 & 72.48 & 68.27 & 0.06 & 147.23 \\
\hline 10 & 3.21 & -0.01 & 1.10 & 4.70 & 75.36 & 62.58 & 0.05 & 146.98 \\
\hline 11 & 4.49 & -0.29 & 2.25 & 4.48 & 89.37 & 19.74 & 0.06 & 120.09 \\
\hline 12 & 2.49 & -2.01 & 0.78 & 4.00 & 63.08 & 53.44 & 0.07 & 121.85 \\
\hline 13 & 0.66 & -3.88 & 0.18 & 1.20 & 36.59 & 56.91 & 0.07 & 91.74 \\
\hline 14 & 1.15 & -2.13 & 0.35 & 1.92 & 50.48 & 66.78 & 0.06 & 118.60 \\
\hline 15 & 1.60 & -0.69 & 0.67 & 1.91 & 71.01 & 57.93 & 0.06 & 132.50 \\
\hline 16 & 1.87 & 0.00 & 0.71 & 2.47 & 72.88 & 74.69 & 0.04 & 152.66 \\
\hline 18 & 0.92 & -1.66 & 0.33 & 1.30 & 53.55 & 71.67 & 0.05 & 126.15 \\
\hline 19 & 3.28 & -2.60 & 0.67 & 8.00 & 55.51 & 45.59 & 0.18 & 110.63 \\
\hline 20 & 2.32 & -1.91 & 0.68 & 3.97 & 60.61 & 72.65 & 0.04 & 138.35 \\
\hline 21 & 3.09 & 0.28 & 1.12 & 4.25 & 77.94 & 78.89 & 0.05 & 165.63 \\
\hline 22 & 3.51 & -1.86 & 1.10 & 5.63 & 69.09 & 70.43 & 0.15 & 148.05 \\
\hline 23 & 2.76 & -0.85 & 1.00 & 3.80 & 72.62 & 64.20 & 0.07 & 143.62 \\
\hline 24 & 2.41 & -3.48 & 0.77 & 3.79 & 57.28 & 47.97 & 0.11 & 108.86 \\
\hline 25 & 1.49 & -0.34 & 0.56 & 1.97 & 68.63 & 63.25 & 0.04 & 135.60 \\
\hline 26 & 0.31 & -3.60 & 0.09 & 0.57 & 32.10 & 66.71 & 0.07 & 96.23 \\
\hline 27 & 1.84 & -0.32 & 0.80 & 2.10 & 76.73 & 66.30 & 0.05 & 147.51 \\
\hline 28 & 1.08 & -1.42 & 0.36 & 1.59 & 55.55 & 46.86 & 0.04 & 104.07 \\
\hline 29 & 1.68 & -1.99 & 0.49 & 2.87 & 55.41 & 63.13 & 0.07 & 121.66 \\
\hline 30 & 2.06 & -2.09 & 0.59 & 3.59 & 57.77 & 72.40 & 0.06 & 134.38 \\
\hline 31 & 2.51 & -1.26 & 0.69 & 4.52 & 61.76 & 48.37 & 0.11 & 116.71 \\
\hline 32 & 1.65 & -3.05 & 0.52 & 2.63 & 52.59 & 40.23 & 0.11 & 94.68 \\
\hline 33 & 3.50 & -0.10 & 1.19 & 5.17 & 75.93 & 57.78 & 0.10 & 143.56 \\
\hline 34 & 3.36 & -5.10 & 0.59 & 9.57 & 50.08 & 50.57 & 0.25 & 109.31 \\
\hline 37 & 1.55 & -1.02 & 0.57 & 2.09 & 64.64 & 53.94 & 0.05 & 121.81 \\
\hline 38 & 1.86 & -2.96 & 0.59 & 2.91 & 55.03 & 36.71 & 0.07 & 94.21 \\
\hline 39 & 2.13 & -0.49 & 0.60 & 3.77 & 61.55 & 61.64 & 0.06 & 129.25 \\
\hline 40 & 2.58 & -0.71 & 1.05 & 3.16 & 75.79 & 62.77 & 0.05 & 144.69 \\
\hline 41 & 1.64 & -1.46 & 0.54 & 2.47 & 60.23 & 19.04 & 0.04 & 82.50 \\
\hline 42 & 3.03 & 1.52 & 1.01 & 4.54 & 77.30 & 64.53 & 0.06 & 152.00 \\
\hline 43 & 2.25 & -5.60 & 0.56 & 4.57 & 48.37 & 67.91 & 0.20 & 118.25 \\
\hline 44 & 0.71 & -2.22 & 0.23 & 1.11 & 45.69 & 59.28 & 0.05 & 104.85 \\
\hline 45 & 4.87 & 0.23 & 2.66 & 4.46 & 95.18 & 18.79 & 0.07 & 126.27 \\
\hline 46 & 2.25 & -3.84 & 0.61 & 4.13 & 53.70 & 67.88 & 0.12 & 124.86 \\
\hline 47 & 2.64 & -2.00 & 0.82 & 4.27 & 63.91 & 73.93 & 0.09 & 143.66 \\
\hline 48 & 2.88 & -2.03 & 0.64 & 6.52 & 56.02 & 52.30 & 0.13 & 116.46 \\
\hline 49 & 1.57 & -0.41 & 0.59 & 2.07 & 68.81 & 49.59 & 0.05 & 122.27 \\
\hline 50 & 3.39 & -1.93 & 1.12 & 5.16 & 69.54 & 30.68 & 0.15 & 108.11 \\
\hline 51 & 2.21 & -0.93 & 0.89 & 2.75 & 72.29 & 58.57 & 0.06 & 135.86 \\
\hline 52 & 1.73 & -6.63 & 0.35 & 4.24 & 40.38 & 36.70 & 0.21 & 76.99 \\
\hline Minimum & 0.31 & -6.63 & 0.09 & 0.57 & 32.10 & 18.79 & 0.03 & 76.99 \\
\hline Maximum & 4.87 & 1.52 & 2.66 & 9.57 & 95.18 & 89.43 & 0.25 & 172.09 \\
\hline Mean & 2.28 & -1.60 & 0.77 & 3.62 & 63.18 & 56.86 & 0.08 & 125.20 \\
\hline
\end{tabular}

\subsection{Permeability index (PI)}

Doneen (1964) to be had water appropriateness classification for irrigation reason base on the permeability index (PI). Permeability index is calculated by using the formula; $\left(\mathrm{PI}=\mathrm{Na}+\sqrt{\mathrm{HCO}_{3}} / \mathrm{Ca}+\mathrm{Mg}+\mathrm{Na} \times 100\right)$, Where, all the values are in meq-1. The PI value of the groundwater ranges from 32.10 to 95.18 with an average values 63.18 . The PI values $>75$ indicate excellent quality of water for irrigation. If the PI values fall in between 25 and 75, they indicate good quality of water for irrigation. However, if the PI values are $<25$, they reflect unsuitable nature of water for irrigation. On the basis of US salinity diagram and Doneen's chart the groundwater in the study area is in general suitable for irrigation purposes (Table 2).

\subsection{Kelly's ratio (KR)}

The Kellys Ratio (Kelly, 1963) values of the study area ranged between 0.09 to 2.66 (Table, 2). These indicate that Most of the KR for the groundwater samples $(83 \%)$ however fall within the permissible limit of 1.0 and are considered suitable for irrigation purposes. 


\subsection{Corrosively ratio index (CRI)}

The magnitude of the corrosiveness of water can be assessed by using a perimeter known as corrositivity ratio Index (CRI), the water having the corrositivity ratio less than one is safe and noncorrosive. Corrositivity ratio greater than two is suggestive of corrosiveness. The corrosively ratio index (CRI) values ranged from 0.03 to $0.25 \mathrm{meq} \mathrm{L}^{-1}$ (Table, 2), indicating groundwater is safe and suitable and less corrosive and hence can be used for domestic or industrial purposes.

\subsection{Magnesium adsorption ratio (MAR)}

Magnesium content of water is considered as one of the most important qualitative criteria in determining the quality of water for irrigation. Generally, calcium and magnesium maintain a state of equilibrium in most waters. More magnesium in water will adversely affect crop yields as the soils become more saline (Joshi et al., 2009; Obiefuna, \& Sheriff, 2011). The values of the magnesium adsorption ratio of groundwater in present study vary from 18.79 to 89.43 (Table, 2). The acceptable limit of MAR is 50 , High MAR affects the soil unfavorably and harmful effect on soils appears when MAR exceeds 50. The waters are therefore, considered suitable $(73 \%)$ and unsuitable $(27 \%)$.

An attempt has been made to develop a model on Irrigation Water Quality Index (IWQI). The various irrigation water quality indices such as SAR, SSP, RSC, PI, and KR were considered to assess the ground water quality for irrigation. The indices value summed, then classified into excellent to unfit groundwater quality (Table 4). The output has shown only $88 \%$ of water slightly unsustainable for irrigation, whereas some parts of the area (12\%) good quality found in water sample.

Table 4: Water Quality Classification Based on WQI Value

\begin{tabular}{|c|c|c|c|c|}
\hline $\begin{array}{l}\text { Water value } \\
\text { range }\end{array}$ & $\begin{array}{l}\text { Water } \\
\text { quality }\end{array}$ & $\begin{array}{l}\text { No.of Samples } \\
\text { (IWQI) }\end{array}$ & $\%$ & Sustainable state \\
\hline$<50$ & Excellent & 0 & 0 & Sustainable \\
\hline $51-100$ & Good & 6 & 12 & Sustainable \\
\hline $101-200$ & Poor & 46 & 88 & $\begin{array}{l}\text { Slightly Unsus- } \\
\text { tainable }\end{array}$ \\
\hline $201-300$ & Very poor & 0 & 0 & Unsustainable \\
\hline$>301$ & Very bad & 0 & 0 & $\begin{array}{l}\text { Highly Sustaina- } \\
\text { ble }\end{array}$ \\
\hline
\end{tabular}

\section{Conclusion}

The present study may help to improve groundwater resource assessment management, achieves social, economic and environmental benefits to support governance and policy. The results have shown that the ground water of study area has been in good in IWQI and maximum samples $(88 \%)$ fall under slightly unsustainable for irrigation. This study can offer the requisite information for the authority to pursue the sustainable approaches on groundwater management and contamination prevention. As the poor quality of irrigation groundwater of restricted for choice of the crops and only defiant crops can grow up successfully. Therefore, it is sturdily desired to improved irrigation practices and develops resistant varieties of crop that can grow without any yield slaughter.

\section{Acknowledgement}

The authors thankful to Director, Groundwater Survey and Development Agency, Pune to providing necessary facility for conducting this research work and granting permission to publish the paper.

\section{References}

[1] Aher,K.R., Patil, Suryakant M., \& Mane V.P. (2015). Preliminary study in Irrigational quality of Groundwater sources in parts of Soygaon block, District Aurangabad, India International Research Journal of Earth Sciences, 3(2), 7-12.

[2] Anbazhagan, S., Das, M.K.,\& Balamurugan, G., (2014). Hydro geo-chemical studies in hard rock aquifer system, Hosur, India. Indian Journal of Geochemistry, 22 (2): 519-535.

[3] APHA (1992). Standard Methods for the Examination of Water and Waste Waters, American Public Health Association, 18th Edition, Washington, DC

[4] Ayers, R. S., \& Westcot, D. W. (1985). Water quality for agriculture (Vol. 29, pp. 37-70). Rome: Fao.

[5] Datta, P. S., \& Tyagi, S. K. (1996). Major ion chemistry of groundwater in Delhi area: chemical weathering processes and groundwater flow regime.Geological Society of India, 47(2), 179188

[6] Deshpande, S. M., \& Aher, K. R. (2011). Hydrogeochemistryand quality assessment of groundwater in Chikalthana industrial area of Aurangabad, Maharashtra, India. Bionano Frontier, 4(1), 157-16.

[7] Doneen, L. D. (1964). Notes on water quality in agriculture. Department of Water Science and Engineering, University of California, Davis

[8] Eaton, F. M. (1950). Significance of carbonates in irrigation waters. Soil science, 69(2), 123-134. https://doi.org/10.1097/00010694195002000-00004

[9] Gowd, S. S. (2005). Assessment of groundwater quality for drinking and irrigation purposes: a case study of Peddavanka watershed, Anantapur District, Andhra Pradesh, India. Environmental Geology, 48(6), 702-712. https://doi.org/10.1007/s00254-005-0009-z.

[10] Handa, B. K. (1969). Description and classification of media for hydro-geochemical investigations. In Symposium on ground water studies in arid and semiarid regions.

[11] Joshi, D.M., A. Kumar \& N. Agrawal, 2009. Assessment of the irrigation water quality of River Ganga in Haridwar District India. J. Chem., 2(2): 285-292

[12] Kaplay, R. D., Patode, H. S., \& Panaskar, D. B. (1998). Groundwater Quality in an Industrial Area of Tuppa, Nanded, Maharashtra. Pollution Research, 17, 251-254.

[13] Karanth, K. R., (1987). Groundwater assessment, development and management, Tata-McGraw Hill Publishing Company Limited, New Delhi

[14] Kelly, W.P., (1963). Use of saline irrigation water. Soil Sci., 95(4): 355-391 https://doi.org/10.1097/00010694-196306000-00003.

[15] Obiefuna, G. I., \& Sheriff, A. (2011). Assessment of shallow ground water quality of Pindiga Gombe Area, Yola Area, NE, Nigeria for irrigation and domestic purposes.

[16] Pawar, N. J., Pondhe, G. M., \& Patil, S. F. (1998). Groundwater pollution due to sugar-mill effluent, at Sonai, Maharashtra, India Environmental Geology, 34(2-3), 151-158. https://doi.org/10.1007/s002540050266.

[17] Purushotham, D., Rao, A. N., Prakash, M. R., Ahmed, S., \& Babu, G. A. (2011). Environmental Impact on Groundwater of Maheshwaram Watershed, Ranga Reddy District, Andhra Pradesh Journal of the Geological Society of India, 77(6), 539-548. https://doi.org/10.1007/s12594-011-0053-0.

[18] Rajankar, P. N., Gulhane, S. R., Tambekar, D. H., Ramteke, D. S. \& Wate, S. R. (2009). Water quality assessment of groundwater resources in Nagpur Region (India) based on WQI. Journal of Chemistry, 6(3), 905-908. https://doi.org/10.1155/2009/971242.

[19] Raju, N. J. (2007). Hydrogeochemical parameters for assessment of groundwater quality in the upper Gunjanaeru River basin, Cuddapah District, Andhra Pradesh, South India. Environmental Geology, 52(6), 1067-1074. https://doi.org/10.1007/s00254-0060546-0.

[20] Rao, P. N., Rao, S. A., \& Rao, N. S. (2015). Suitability of groundwater quality for drinking, irrigation and industrial purposes in the Western Delta Region of the River Godavari, Andhra Pradesh. Journal of the Geological Society of India, 86(2), 181-190. https://doi.org/10.1007/s12594-015-0297-1.

[21] Reddy, K. S. (2013). Assessment of groundwater quality for irrigation of Bhaskar Rao Kunta watershed, Nalgonda District, India. International Journal of Water Resources and Environmental Engineering, 5(7), 418-425.

[22] Richards, L. A. (1954). Diagnosis and improvement of saline and

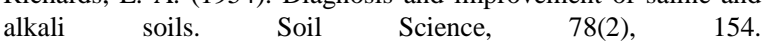
https://doi.org/10.1097/00010694-195408000-00012. 
[23] Shashi kant., Singh, Y. V., Jat, L. K., Meena, R., \& Singh, S. N. (2015). Assessment of ground water quality of lahar block, Bhind district in Madhya Pradesh, International Journal of Advanced Geosciences, 3(2), 38-41.

[24] Subba Rao, N., \& Krishna Rao, G. (1991). Groundwater quality in Visakhapatnam urban area, Andhra Pradesh. Indian Journal of Environmental Health, 33(1), 25-30.

[25] Tatawat, R. K., \& Chandel, C. S. (2008). A hydrochemical profile for assessing the groundwater quality of Jaipur City. Environmental monitoring and assessment, 143(1-3), 337-343. https://doi.org/10.1007/s10661-007-9936-3.

[26] U.S. Department of Agriculture, (1954) U.S. Salinity Laboratory Staff, Diagnosis and Improvement of Saline and Alkali Soils. Handbook 60. Washington, D.C.

[27] Vijay, R., Khobragade, P., \& Mohapatra, P. K. (2011). Assessment of groundwater quality in Puri City, India: an impact of anthropogenic activities. Environmental monitoring and assessment, 177(14), 409-418. https://doi.org/10.1007/s10661-010-1643-9.

[28] Wani,Rifat Ara, Aabid Hussain Mir, Aasimah Tanveer, Arshid Jehangir,\& A. R. Yousuf., ( 2014). Preliminary study on irrigational quality of some ground water sources of Kashmir, India, International Journal of Scientific \& Engineering Research, Vol. 5(2), 318 323.

[29] Wijnen, M., Augeard B., Hiller, B., Ward C \& Huntjens P., (2012). Managing the invisible understanding and improving groundwater governance, World Bank http://www.worldbank.org/water. Draft Report no. 10 . 